\title{
Reduksi Purin pada Emping Melinjo Melalui Pre-treatment Perendaman Emping Mentah
}

\author{
Reduction of Purines in Fried Melinjo Chips (Fried Emping) \\ through Soaking Pre-treatment
}

\author{
Hanifah Nuryani Lioe*, Dahrul Syah, Annisa Defriana \\ Departemen Ilmu dan Teknologi Pangan, Fakultas Teknologi Pertanian, Institut Pertanian Bogor, Bogor
}

\begin{abstract}
Melinjo chips (emping as local name) has high purine content which can be related to the high uric acid level in blood that lead to joint inflamation due to the sendimentation of uric acid. The objective of this research is to prove that soaking process can reduce purine content in emping and to know the effect of the soaking process length in purine reduction. Soaking time (2, 5, and 12 hours) and emping brand (Sriti, Al and Koki) were used as the treatments. Purine compounds such as adenine and hypoxanthine were analyzed by using High Performance Liquid Chromatography (HPLC) method with C18 column and $U V$ detector. The three emping samples were also analyzed by using sensory evaluation to know the consumer preference toward the treated fried emping. Results obtained from this research were that soaking process can reduce both adenine and hypoxanthin content in emping. Soaking for 2 hours in water could reduce adenine content $13-39 \%$ and hypoxanthine content $4-60 \%$. Soaking process for 2 hours on emping could reduce up to 50\% of total purine base content in Al brand, however, soaking time was not directly proportional to the decrease in purine levels. Purine content after 5 and 12 hours soaking tend to be fluctuative. Emping samples that were soaked in the water have a decrease in preference by the panelists either in color, aroma, taste, texture or in overall, but still accepted by panelists.
\end{abstract}

Keywords: adenine, emping (belinjo cracker), hypoxanthine, HPLC, purine reduction

\begin{abstract}
Abstrak. Emping melinjo mengandung basa purin yang relatif tinggi. Hal ini sering dikaitkan sebagai penyebab tingginya kadar asam urat dalam darah yang kemudian berdampak pada peradangan akibat penumpukan kristal asam urat dalam sendi. Penelitian ini bertujuan untuk membuktikan bahwa proses perendaman emping mentah dalam air mampu mengurangi sejumlah senyawa purin yang terkandung dalam emping sebelum digoreng. Lama proses perendaman (2, 5, dan 12 jam) dan merek emping (Sriti, A1, Koki) menjadi parameter. Senyawa purin yaitu adenin dan hiposantin dalam sampel dianalisis menggunakan High Performance Liquid Chromatography (HPLC) dengan kolom C18 dan detector UV. Sampel selanjutnya diuji secara organoleptik untuk mengetahui tingkat kesukaan konsumen terhadap hasil perlakuan sampel yang telah digoreng. Hasil penelitian menunjukkan bahwa perendaman emping melinjo dalam air mampu menurunkan kadar adenin dan hiposantin emping tersebut. Perendaman selama 2 jam mampu menurunkan kadar adenin 13 - 39\% dan kadar hiposantin $4-60 \%$. Proses perendaman emping selama 2 jam dalam air mampu menurunkan total basa purin hingga $50 \%$ pada emping dari merek A1, akan tetapi lama perendaman tidak berbanding lurus dengan penurunan kadar purin. Kadar purin setelah 5 dan 12 jam perendaman cenderung fluktuatif. Emping melinjo yang telah diberikan perlakuan perendaman dalam air mengalami penurunan kesukaan oleh panelis dari segi warna, rasa, aroma, tekstur dan overall namun masih dapat diterima secara organoleptik oleh konsumen.
\end{abstract}

Kata Kunci: adenin, emping melinjo, hiposantin, HPLC, reduksi purin

Aplikasi Praktis. Metode pengolahan emping melinjo yang diusulkan dari hasil penelitian ini dapat
diterapkan oleh produsen emping untuk memproduksi emping rendah purin agar dapat dikonsumsi oleh
konsumen yang lebih luas termasuk konsumen yang menderita asam urat.

\section{PENDAHULUAN}

Emping merupakan salah satu pangan tradisional Indonesia yang dibuat dari biji melinjo (Gnetum gnemon L). Menurut Haryoto (1998), karena rasanya yang khas, emping banyak dikonsumsi sebagai cemilan ataupun pelengkap berbagai masakan Indonesia. Namun, sampai saat ini banyak masyarakat menghindari konsumsi emping berlebihan. Hal ini dikarenakan emping memiliki kandungan purin yang relatif tinggi, yaitu berkisar antara $50-150 \mathrm{mg} / 100 \mathrm{~g}$ bahan (Munajad 2009). Menurut Choi et al. (2005) dan Tarkeltaub (2010), kandungan purin yang tinggi pada bahan pangan dapat menyebabkan tingginya kadar asam urat dalam darah. Hal ini dapat 
menyebabkan peradangan yang diakibatkan penumpukan kristal asam urat pada sendi atau biasa disebut gout (Tarkeltaub 2010). Emping melinjo sebenarnya memiliki senyawa lain yaitu reverastrol yang justru dapat menurunkan asam urat dalam darah, akan tetapi hanya ekstrak melinjo yang mampu memiliki reverastrol pada kadar yang mampu menurunkan asam urat tersebut (Konno et al. 2013). Dalam penelitian ini melinjo digunakan secara utuh dalam bentuk emping, sehingga potensi kadar purinnya dapat meningkatkan asam urat.

Upaya menyediakan pangan rendah purin bagi penderita asam urat (hyperuricemia) atau kelompok yang beresiko terkena asam urat menjadi sangat penting. Saat ini upaya mereduksi purin pada aneka jenis makanan masih terbatas, terutama untuk produk yang memiliki kadar purin tinggi. Daging, ikan, rumput laut, jamur dikenal memiliki kadar purin yang relatif tinggi (Kaneko et al. 2014, Sayuti et al. 2019). Reduksi purin pada emping dapat dijadikan salah satu upaya agar penderita asam urat tetap dapat mengkonsumsi emping. Oleh karena itu, preparasi sebelum proses penggorengan melalui proses perendaman dalam air diharapkan dapat menjadi solusi untuk mengurangi kadar purin pada emping sehingga aman dikonsumsi setelah digoreng. Purin adalah basa dari asam nukleat yang dapat larut dalam air (Herskovits dan Harrington, 1972), sehingga perlakuan perendaman dalam air memungkinkan senyawa ini larut dalam air yang digunakan untuk merendam emping mentah, sehingga residunya dalam emping akan menurun. Di samping itu, upaya reduksi purin lainnya yang dilakukan dengan cara enzimatis menggunakan enzim xanthine oxidoreductase (Jankowska et al. 2013) masih terbatas aplikasinya untuk industri pangan karena harga enzim yang umumnya relatif mahal.

Tujuan penelitian ini adalah mereduksi kadar purin pada produk emping melalui perendaman dalam air. Perendaman yang dimaksud adalah perendaman emping mentah dalam air dan kemudian dilakukan penjemuran kembali, sebelum proses penggorengan. Cara ini merupakan pre-treatment sebelum penggorengan emping yang sederhana sehingga dapat juga dilakukan oleh konsumen apabila konsumen menghendaki emping dengan kadar purin rendah. Prosedur perendaman dan penjemuran kembali untuk produsen emping juga direkomendasikan dalam penelitian ini untuk menghasilkan produk rendah purin.

\section{BAHAN DAN METODE}

\section{Bahan dan alat}

Bahan yang digunakan adalah emping melinjo siap goreng yang berasal dari 3 merek yang berbeda yang dibeli di supermarket di kota Bogor. Air untuk perendaman berupa air ledeng. Untuk penyimpanan, digunakan plastik PP yang relatif tebal. Bahan yang diperlukan untuk keperluan analisis adalah asam fosfat (p.a., Merck, Jerman), metanol (p.a., Merck, Jerman), etanol (p.a.,
Merck, Jerman), aquabidest, dan larutan standar purin (adenin dan hiposantin) (Sigma, Aldrich, US).

Alat yang diperlukan adalah alat pengolahan berupa baskom, saringan plastik, loyang aluminium dan timbangan digital. Untuk keperluan analisis, alat yang digunakan adalah sudip, HPLC model LC 6A (Shimadzu, Shimadzu Corp., Kyoto, Jepang) dilengkapi dengan detektor UV model SPD-10AV (Shimadzu, Shimadzu Corp., Kyoto, Jepang) dan kolom C18 (Zorbax, Agilent Technologies, USA), oven, blender MX-T2GN (National, Taipei, Taiwan), magnetic stirrer, hot plate, pompa vakum, neraca analitik, peralatan gelas dan membran nilon $(0.45 \mu \mathrm{m})$.

\section{Orientasi proses perendaman emping}

Tujuan orientasi proses perendaman ini adalah untuk memperoleh prosedur perendaman dalam air yang memberikan hasil penurunan kadar basa purin. Tahapan perendaman dilakukan sesuai dengan Gambar 1A. Orientasi meliputi penentuan lama proses perendaman emping serta lama proses penjemuran. Perendaman dilakukan dengan menambahkan air sebanyak $800 \mathrm{~mL}$ pada $100 \mathrm{~g}$ emping mentah dalam wadah baskom. Waktu perendaman ditentukan dengan parameter bentuk dan tekstur emping yang direndam. Emping yang direndam tidak boleh hancur ataupun terurai (masih bisa diambil menggunakan tangan). Penjemuran dilakukan hingga emping kering dengan kadar air kurang dari 14\%. Kondisi ini sama seperti emping mentah pada umummya (keras dan tidak lengket). Lama penjemuran yang diamati tersebut diterapkan pada proses selanjutnya. Diagram alir berdasarkan hasil orientasi proses dapat dilihat pada Gambar 1B.

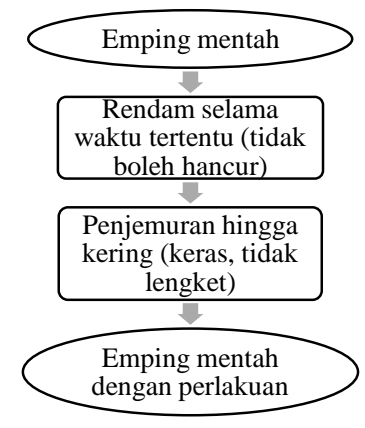

A

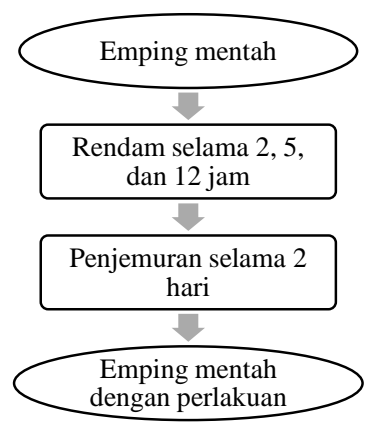

B
Gambar 1.Tahapan perendaman emping untuk orien-tasi proses $(A)$, hasil orientasi proses $(B)$

\section{Pengambilan sampel}

Sampel yang dipilih merupakan emping yang paling banyak ditemukan di swalayan. Merek emping yang berbeda menunjukan daerah atau produsen yang berbeda. Pengambilan sampel dilakukan dengan mengambil tiga merek emping melinjo berbeda yang berada di tiga swalayan yang berada di kota Bogor. Spesifikasi sampel dapat dilihat pada Tabel 1. 
Tabel 1. Deskripsi sampel emping melinjo mentah yang dipakai dalam penelitian reduksi basa purin

\begin{tabular}{|c|c|c|c|}
\hline \multirow{2}{*}{ Deskripsi } & \multicolumn{3}{|c|}{ Merek Sampel } \\
\hline & Sriti & A1 & Koki \\
\hline $\begin{array}{l}\text { Produsen } \\
\text { Alamat } \\
\text { Produsen }\end{array}$ & $\begin{array}{c}\text { Sriti Food } \\
\text { Jakarta }\end{array}$ & $\begin{array}{c}\text { A1 } \\
\text { Semarang }\end{array}$ & $\begin{array}{l}\text { Surya Abadi } \\
\text { Bandung }\end{array}$ \\
\hline Komposisi & Melinjo & Melinjo & Melinjo \\
\hline Kemasan & $\begin{array}{l}\text { Plastik PP } \\
\text { tebal }\end{array}$ & $\begin{array}{l}\text { Plastik PP } \\
\text { tebal }\end{array}$ & $\begin{array}{l}\text { Plastik PP } \\
\text { tebal }\end{array}$ \\
\hline $\begin{array}{l}\text { Berat per } \\
\text { kemasan }\end{array}$ & $250 \mathrm{~g}$ & $500 \mathrm{~g}$ & $200 \mathrm{~g}$ \\
\hline $\begin{array}{l}\text { Warna } \\
\text { Ketebalan } \\
\text { bahan }\end{array}$ & $\begin{array}{l}\text { Kuning cerah } \\
\text { Agak tebal }\end{array}$ & $\begin{array}{c}\text { Kuning cerah } \\
\text { Tipis }\end{array}$ & $\begin{array}{l}\text { Kuning cerah } \\
\text { Agak tebal }\end{array}$ \\
\hline
\end{tabular}

\section{Percobaan reduksi purin pada emping melinjo}

Reduksi purin dilakukan dengan merendam emping dalam air (perbandingan 1:8) dimana $100 \mathrm{~g}$ emping melinjo direndam dalam $800 \mathrm{~mL}$ air. Penjemuran kembali emping yang telah direndam sesuai dengan hasil orientasi proses perendaman. Faktor yang diamati pada penelitian utama adalah lama proses perendaman emping, yaitu 2, 5, dan 12 jam. Perendaman dilakukan selama waktu yang ditentukan. Emping tersebut lalu ditiriskan satu per satu menggunakan tangan dan dijemur pada loyang alumunium selama 2 hari dengan ketebalan penjemuran yaitu 1 lapisan emping. Setelah kering, emping dikemas pada plastik PP tebal dan disimpan di lemari pendingin. Proses perendaman dapat dilihat pada Gambar 2A sedangkan proses penjemuran dapat dilihat pada Gambar 2B. Ulangan percobaan adalah dua kali ulangan.
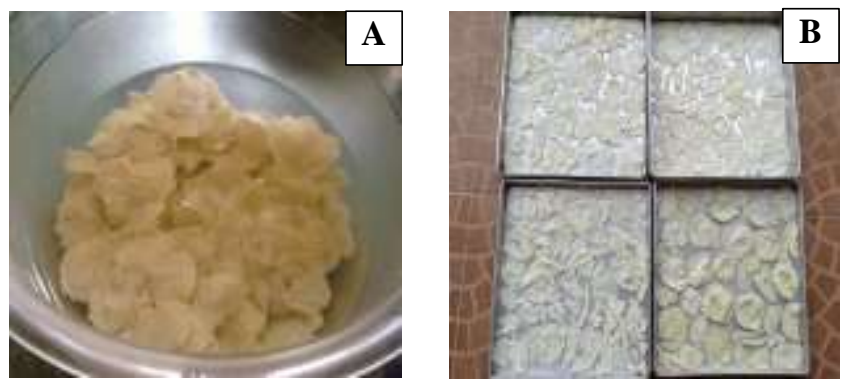

Gambar 2. Proses perendaman (A), proses penjemuran (B)

\section{Analisis purin pada emping melinjo}

Metode yang digunakan dalam analisis purin mengacu pada metode yang digunakan Xue et. al. (2009) dengan modifikasi pada laju alir dan metode elusi fase gerak menjadi isokratik.

Larutan stok standar adenin dan hiposantin (0.5 $\mathrm{mg} / \mathrm{mL}$ ) disiapkan dengan melarutkan standar (bubuk) dalam campuran asam fosfat $0.4 \%$ dan metanol. Masingmasing standar diinjeksikan ke HPLC untuk mendapatkan waktu retensi masing masing standar. Selanjutnya standar adenin dan hiposantin dicampurkan untuk membuat satu seri larutan standar campuran. Untuk memperoleh kurva standar, larutan standar campuran diencerkan dengan pelarut berupa campuran asam fosfat dan metanol hingga diperoleh larutan dengan beberapa konsentrasi sebelum diinjeksikan ke dalam HPLC. Konsentrasi larutan standar yang digunakan adalah 250,
$125,62.5,31.2,15.6,7.8,3.9$ dan $2.0 \mu \mathrm{g} / \mathrm{mL}$. Larutan stok dan standar disimpan pada suhu $4^{\circ} \mathrm{C}$.

Untuk preparasi sampel, sampel emping yang telah dihaluskan dengan chopper ditimbang sebanyak $0.5 \mathrm{~g}$. Sampel selanjutnya dihidrolisis dengan menambahkan $0.5 \mathrm{~mL} \mathrm{HCl} \mathrm{6M}$ dan memanaskannya di air mendidih selama 60 menit. Setelah dingin, sampel dinetralkan dengan $\mathrm{NH}_{4} \mathrm{OH} 25 \%$ dan kemudian divortex hingga teraduk rata. Campuran tersebut kemudian ditepatkan hingga $10 \mathrm{~mL}$ dengan aquabidest dalam labu takar 10$\mathrm{mL}$. Sebelum diinjeksikan ke dalam kolom, larutan dilewatkan melalui kolom solid phase extraction (SPE) yang berisi kurang lebih $1 \mathrm{~g}$ silika yang telah diaktivasi dengan pengeringan selama 17 jam dalam oven suhu $105^{\circ} \mathrm{C}$. Analisis purin pada sampel dan larutan standar menggunakan HPLC yang sesuai dengan kondisi pada Tabel 2.

Tabel 2. Kondisi operasi analisis purin dengan HPLC-UV (LC-6A, Shimadzu, Jepang)

\begin{tabular}{|c|c|}
\hline Kriteria & Kondisi \\
\hline Kolom & $\begin{array}{l}\text { Zorbax C18 (ODS), ukuran partikel } \\
\text { pendukung } 5 \mu \mathrm{m} \text {, panjang } 250 \mathrm{~mm} \text {, diameter } \\
\text { dalam } 4.6 \mathrm{~mm}\end{array}$ \\
\hline Suhu running & Suhu ruang $30^{\circ} \mathrm{C}$ \\
\hline Fase gerak & $\begin{array}{l}\text { Asam fosfat } 0.4 \%(90 \%) \text { dan metanol p.a. } \\
(10 \%) \text { dengan penyesuaian pH } \\
\text { mengqunakan } \mathrm{NH}_{4} \mathrm{OH} 1 \mathrm{M} \text { hingga } \mathrm{pH} 4.0\end{array}$ \\
\hline $\begin{array}{l}\text { Laju aliran } \\
\text { fase gerak }\end{array}$ & $0.5 \mathrm{~mL} / \mathrm{menit}$ \\
\hline $\begin{array}{l}\text { Deteksi } \\
\text { Sampel loop }\end{array}$ & $\begin{array}{l}\text { UV } 257 \mathrm{~nm} \\
20 \mu \mathrm{L}\end{array}$ \\
\hline
\end{tabular}

Konsentrasi komponen purin dalam sampel dapat ditentukan dari kurva standar, yaitu dengan memasukkan data luas area senyawa purin dalam kromatogram sampel. Kandungan purin ( $\mu \mathrm{g}$ per gram sampel) dapat dihitung melalui konsentrasi senyawa purin yang diketahui dari kurva standar $(\mu \mathrm{g} / \mathrm{mL})$, dikalikan dengan volume larutan sampel analitik $(10 \mathrm{~mL})$ serta faktor pengencerannya, kemudian dibagi dengan bobot sampel (g). Uji unjuk kerja analisis (analytical performance) dilakukan mengikuti metode AOAC (2012) yang terdapat pada Appendix K, untuk menentukan linearitas, limit deteksi (Limit of Detection atau LOD), limit kuantifikasi (Limit of Quantification atau LOQ), akurasi dan presisi.

\section{Analisis kadar air metode oven}

Penentuan kadar air dengan metode oven dilakukan mengikuti metode AOAC (2012) dengan mengeluarkan air dari sampel dengan pengeringan menggunakan oven. Analisis ini didasarkan pada pengukuran berat yang hilang akibat pengeringan. Mulanya, cawan kosong dan tutupnya dikeringkan, lalu didinginkan. Masukkan 1-2 g sampel ke dalam cawan yang telah dikeringkan kemudian cawan berisi bahan tersebut dikeringkan dalam oven yang bersuhu $105^{\circ} \mathrm{C}$ selama $3 \mathrm{jam}$. Kadar air sampel ditentukan basis kering dan basis basah.

\section{Penurunan senyawa purin}

Penurunan senyawa basa purin dapat dihitung dengan membandingkan konsentrasi senyawa purin pada 
sampel sebelum dan sesudah diberikan perlakuan. Penurunan senyawa purin dapat dihitung melalui rumus berikut:

Penurunan kadar adenin $(K A)=$

$$
\frac{\text { KA sampel A-KA sampel B }}{\text { KA sampel A }} \times 100 \%
$$

Penurunan kadar hiposantin $(K H)=$

$$
\frac{\text { KH sampel A-KH sampel B }}{\text { KH sampel A }} \times 100 \%
$$

Penurunan basa purin total $=$

$$
\frac{((\mathrm{KA}+\mathrm{KH}) \text { sampel } \mathrm{A})-((\mathrm{KA}+\mathrm{KH}) \text { sampel B })}{(\mathrm{KA}+\mathrm{KH}) \text { sampel A }} \times 100 \%
$$

dimana, KA: Kadar adenin; KH: Kadar hiposantin; A : emping sebelum perlakuan perendaman; B: emping setelah perlakuan perendaman.

\section{Uji organoleptik}

Uji organoleptik dengan menggunakan uji rating hedonik dilakukan terhadap 70 orang panelis tidak terlatih (kisaran umur 20-22 tahun, dengan jumlah lakilaki dan wanita yang seimbang). Uji hedonik mengikuti gambaran yang terdapat dalam penelitian Lim (2011) tetapi menggunakan 7 skala, bukan 9 skala hedonik. Uji ini dilakukan untuk mengetahui tingkat kesukaan (hedonik) konsumen terhadap produk. Parameter yang diuji antara lain warna, aroma, rasa, tekstur, dan overall. Sampel yang diuji adalah emping Sriti yang mewakili sampel yang mengalami penurunan kadar adenin, dan sampel A1 yang mewakili sampel yang mengalami penurunan kadar hiposantin. Masing-masing panelis diberi sampel yang telah diberi perlakuan perendaman 2 jam yang terpilih dari hasil penelitian reduksi basa purin dan juga sampel kontrol.

Panelis menerima delapan sampel emping melinjo yang telah digoreng yang terdiri dari dua sampel kontrol Sriti, dua sampel perlakuan Sriti, dua sampel kontrol A1 dan dua sampel perlakuan A1. Sampel kontrol merupakan emping yang tidak diberi perlakuan apapun sedangkan sampel perlakuan merupakan emping yang telah mengalami proses perlakuan perendaman pada waktu terpilih dan proses penjemuran kembali selama dua hari. Panelis diminta untuk menilai tingkat kesukaan mereka terhadap warna, aroma, rasa, tekstur dan penampilan keseluruhan produk. Skala hedonik yang digunakan untuk penilaian adalah 1 sampai 7 dengan ketentuan $1=$ sangat tidak suka, $2=$ tidak suka, $3=$ agak tidak suka, $4=$ netral, $5=$ agak suka, $6=$ suka dan $7=$ sangat suka.

\section{Analisis statistik}

Data hasil analisis purin serta hasil uji hedonik diolah dengan one-way analysis of variance (ANOVA) untuk mengetahui perbedaan nyata antara perlakuan, menggunakan SPSS versi 20.0 tahun 2011 (IBM, Amerika Serikat) dan apabila berbeda nyata maka dilakukan uji lanjutan dengan uji Duncan.

\section{HASIL DAN PEMBAHASAN}

\section{Hasil uji unjuk kerja analisis basa purin dengan HPLC-UV}

Unjuk kerja analisis basa purin dengan HPLC-UV yang mengikuti metode AOAC (2012) diawali dengan pembuatan kurva standar dengan menginjeksi standar pada beberapa konsentrasi tertentu. Injeksi awal dilakukan pada masing masing standar (adenin dan hiposantin) untuk mengetahui waktu retensi masing masing senyawa. Waktu retensi hiposantin yaitu pada 4 5 menit, sedangkan adenin pada 5 - 6 menit.

Penentuan konsentrasi basa purin dalam sampel menggunakan kurva standar dengan persamaan: $\mathrm{y}=$ $44086 \mathrm{x}+85811$ dan $\mathrm{R}^{2}=0.9993$ untuk hiposantin, kemudian dengan $y=66298 x+92095$ dan $R^{2}=0.9999$ untuk adenin. Analisis adenin dan hiposantin dapat dilakukan secara simultan (bersamaan) pada range konsentrasi $1.95-250 \mu \mathrm{g} / \mathrm{mL}$ basa purin. Metode analisis ini memiliki Limit of Detection (LOD) dan Limit of Quantitation (LOQ) sebesar $0.69 \mu \mathrm{g} / \mathrm{mL}$ dan $2.3 \mu \mathrm{g} / \mathrm{mL}$ untuk hiposantin serta $0.72 \mu \mathrm{g} / \mathrm{mL}$ dan $2.4 \mu \mathrm{g} / \mathrm{mL}$ untuk adenin. Selain itu, untuk pengukuran dengan range konsentrasi $100-1000 \mu \mathrm{g} / \mathrm{g}$ (menggunakan uji rekoveri dengan sampel emping), metode analisis ini memiliki akurasi sebesar $66.75-100.15 \%$ dan presisi sebesar 2.22 - 3.15\% untuk hiposantin serta akurasi sebesar 79.33 90.37\% dan presisi sebesar $3.46-5.19 \%$ untuk adenin. Hasil ini valid apabila purin (adenin atau hiposantin) terdapat dalam emping sekitar $1000 \mu \mathrm{g} / \mathrm{g}$ sampel. Kromatogram analisis adenin dan hiposantin pada sampel emping ditunjukkan pada Gambar 3.

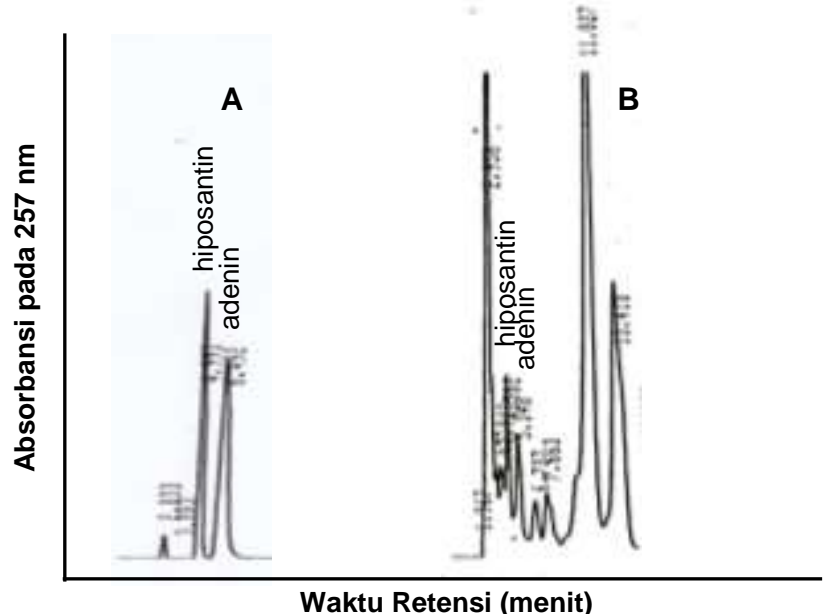

Gambar 3. Kromatogram basa purin $62.5 \mu \mathrm{g} / \mathrm{mL}$ dalam larutan standar (A) dan sampel emping (B). Waktu retensi hiposantin yaitu pada $4-5$ menit dan adenin pada 5 - 6 menit.

Reduksi adenin dan hiposantin pada emping melinjo

Kandungan purin emping melinjo pada masing masing merek dapat dilihat pada Tabel 3. Emping melinjo dianggap memiliki kandungan purin yang relatif tinggi. Berdasarkan hasil penelitian (Tabel 3), konsentrasi adenin pada sampel berkisar antara 111-186 $\mu \mathrm{g} / \mathrm{g}$ bk yang hampir serupa dengan kadar adenin pada olahan kacang 
kedelai yaitu tahu goreng dan serealia yaitu sekitar 200 $\mu \mathrm{g} / \mathrm{g}$, tetapi lebih kecil daripada olahan kedelai fermentasi (natto) yang dapat mencapai $450 \mu \mathrm{g} / \mathrm{g}$, serta jauh lebih rendah dibandingkan beberapa jenis sayuran, rumput laut nori dan jamur shiitake yang dapat mencapai 800 hingga $2100 \mu \mathrm{g} / \mathrm{g}$ (Kaneko et. al. 2014).

Tabel 3. Konsentrasi adenin dan hiposantin dalam sampel emping melinjo dari berbagai merek

\begin{tabular}{lccc}
\hline \multirow{2}{*}{ Merek Sampel } & \multicolumn{3}{c}{ Konsentrasi $(\mu \mathbf{g} / \mathbf{g ~ b k})^{\star}$} \\
\cline { 2 - 4 } & Adenin & Hiposantin & Total $^{\star}$ \\
\hline \multirow{2}{*}{ Koki } & $186.05^{\mathrm{b}} \pm$ & $144.79^{\mathrm{a}} \pm$ & $330.84^{\mathrm{a}} \pm$ \\
& 0.47 & 8.44 & 7.97 \\
A1 & $111.78^{\mathrm{a}} \pm$ & $368.07^{\mathrm{b}} \pm$ & $479.84^{\mathrm{b}} \pm$ \\
& 1.33 & 13.12 & 14.45 \\
Sriti & $132.00^{\mathrm{a}} \pm$ & $151.44^{\mathrm{a}} \pm$ & $283.44^{\mathrm{a}} \pm$ \\
& 18.45 & 57.91 & 76.35 \\
\hline
\end{tabular}

Keterangan : * Hasil menunjukkan nilai rata-rata dan standar deviasi dari 2 ulangan percobaan. Nilai yang diikuti dengan huruf yang sama pada kolom yang sama menunjukan nilai yang tidak berbeda nyata $(\mathrm{p}<0.05)$. Total konsentrasi adalah total dari basa purin (adenin dan hiposantin)

Konsentrasi hiposantin pada sampel berkisar antara 144-368 $\mu \mathrm{g} / \mathrm{g}$ bk yang sebanding kadarnya dengan sayuran parsley, namun lebih tinggi dibandingkan beberapa olahan kacang kedelai dan beberapa jenis jamur yang kadarnya kurang dari $80 \mu \mathrm{g} / \mathrm{g}$ (Kaneko et. al. 2008, Kaneko et. al. 2014). Apabila dibandingkan dengan hasil penelitan terbaru dengan bahan pangan yang terdapat di Indonesia, maka kadar adenin dan hiposantin yang ditemukan dalam penelitian ini jauh lebih rendah daripada yang dilaporkan oleh Sayuti et al. (2019) dimana kadar purin dalam jeroan ayam dapat mencapai $8500 \mu \mathrm{g} / \mathrm{g}$ bk.

Berdasarkan uji ANOVA, diketahui bahwa kadar adenin dan hiposantin dari sampel yang diuji berbeda nyata antar masing masing merek emping melinjo. Kadar adenin dan hiposantin yang beragam pada seluruh sampel emping melinjo kemungkinan besar dikarenakan perbedaan ukuran, ketebalan, maupun karakteristik melinjo sebagai bahan baku sampel itu sendiri. Selain itu, terdapat kemungkinan bahwa biji melinjo yang digunakan sebagai bahan baku sampel berasal dari varietas berbeda karena sampel berasal dari beberapa daerah yang berbeda. Kemungkinan lainnya adalah proses pembuatan masing masing sampel yang berbeda. Walaupun secara garis besar proses pembuatannya sama, setiap produsen pasti memiliki cara tertentu dalam setiap proses pembuatan.

Reduksi adenin dan hiposantin pada emping melinjo dilakukan dengan merendam emping mentah yang berasal dari berbagai merek yang berbeda dengan air pada suhu ruang selama waktu tertentu. Grafik perubahan konsentrasi hiposantin dan adenin setelah penerapan proses perendaman dapat dilihat pada Gambar 4 dan 5 . Konsentrasi adenin pada sampel Sriti mengalami penurunan seiring lama proses perendaman. Sampel Koki, dan A1 juga cenderung mengalami penurunan walaupun agak fluktuatif. Namun, penurunan paling jelas terlihat setelah 2 jam perendaman terhadap seluruh sampel. Jika dilihat secara umum, penurunan konsentrasi hiposantin hanya terjadi pada sampel A1 dimana terdapat penurunan konsentrasi hiposantin seiring lama proses perendaman.
Pada sampel Koki dan Sriti penurunan konsentrasi hiposantin hanya terjadi pada saat perendaman selama 2 jam.

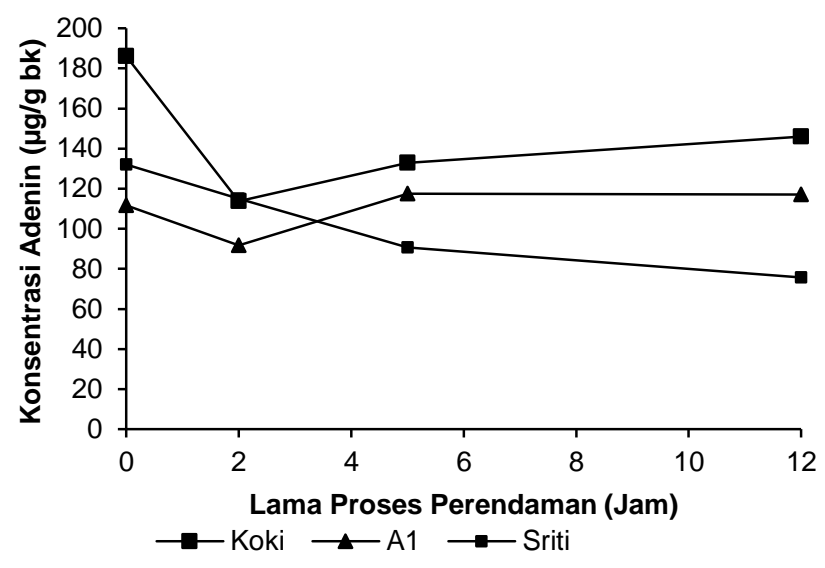

Gambar 4. Perubahan konsentrasi adenin dalam sampel emping melinjo dari swalayan yang direndam dalam air dan selanjutnya dijemur

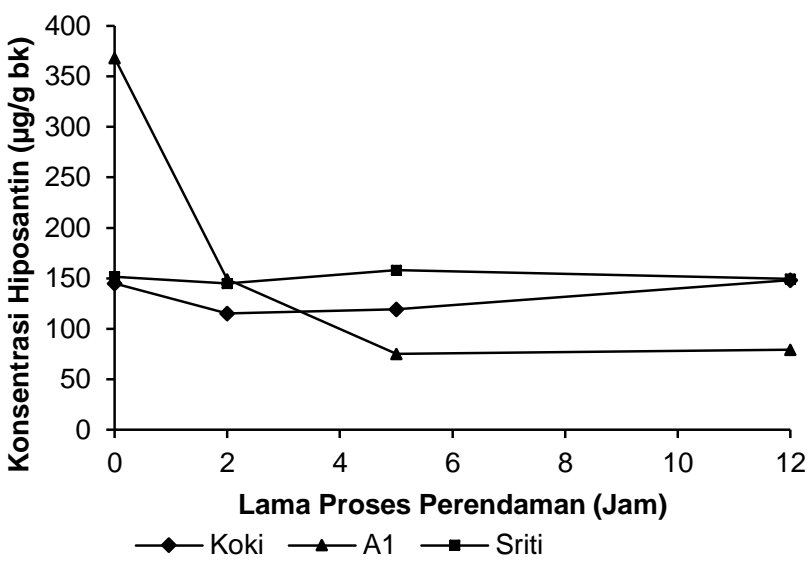

Gambar 5. Perubahan konsentrasi hiposantin dalam sampel emping melinjo dari swalayan yang direndam dalam air dan selanjutnya dijemur

Hal ini menunjukan bahawa perendaman selama 2 jam telah mampu menurunkan kadar purin. Penurunan konsentrasi adenin pada sampel Sriti dan hiposantin pada sampel A1 menunjukan bahwa proses perendaman mampu mengurangi kadar adenin dan hiposantin sampel. Namun, setelah proses perendaman 2 jam, kadar adenin dan hiposantin relatif stabil, atau tidak mengalami penurunan. Dalam hal ini, sebagian adenin dan hiposantin yang cenderung polar larut ke dalam air rendaman selama proses perendaman 2 jam. Kadar hiposantin pada sampel Srti dan Koki relatif tetap selama perendaman dikarenakan kadar hiposantin yang relatif rendah pada awalnya.

Penurunan kadar purin, baik adenin dan hiposantin pada sampel yang cukup rendah dapat dipengaruhi oleh karakteristik fisik dari sampel yang diuji. Sampel yang diuji merupakan emping mentah atau bisa disebut emping siap goreng. Karakter fisik dari sampel yaitu teksturnya yang keras dengan pori berukuran kecil. Hal ini dikarenakan sampel yang diuji telah mengalami proses pengeringan sebelumnya, yaitu proses pengeringan selama pembuatan emping sesaat setelah proses pemi-pihan. 
Tahap pengeringan awal ini menyebabkan case hardning yang menghambat penyerapan air pada proses selanjutnya (Muchtadi dan Ayustaningwarno 2010). Pori yang kecil akibat adanya case hardening tentu memengaruhi proses perendaman untuk menurunkan kadar purin. Air akan lebih sulit terserap sehingga proses perendaman menjadi kurang efektif.

\section{Penurunan konsentrasi adenin dan hiposantin pada emping melinjo setelah perendaman selama 2 jam}

Berdasarkan percobaan, diketahui bahwa seluruh sampel yang diuji mengalami penurunan kadar adenin dan hiposantin setelah perendaman selama 2 jam. Presentase penurunan kadar adenin dan hiposantin setelah proses perendaman selama 2 jam dapat dilihat pada Tabel 4.

Tabel 4. Penurunan kadar adenin dan hiposantin pada emping melinjo setelah perendaman selama 2 jam dalam air

\begin{tabular}{lccc}
\hline \multirow{2}{*}{ Merek Sampel } & \multicolumn{3}{c}{ Penurunan Konsentrasi (\%) } \\
\cline { 2 - 4 } & Adenin & Hiposantin & Total $^{\star}$ \\
\hline Koki & 38.85 & 20.45 & 30.80 \\
A1 & 17.94 & 59.54 & 49.85 \\
Sriti & 12.81 & 4.40 & 8.32 \\
\hline Keterangan: *penurunan total dari basa purin (adenin dan hiposantin)
\end{tabular}

Pada Tabel 4, terlihat jelas bahwa emping yang telah mengalami perlakuan perendaman selama 2 jam mengalami penurunan kadar adenin 13 - 39\% dan penurunan kadar hiposantin $4-60 \%$ jika dibandingkan dengan emping melinjo mentah tanpa perlakuan perendaman. Jika adenin dan hiposantin dianggap dapat mewakilkan total basa purin pada emping, maka penurunan total basa purin dapat dihitung. Penurunan total basa purin setelah proses perendaman emping selama 2 jam berkisar antara $8-50 \%$. Hal ini menunjukan bahwa proses perendaman emping selama 2 jam dalam air mampu menurunkan total basa purin hingga 50\%. Jika melihat presentase penurunan kadar purin pada masing masing merek emping, emping Koki dan A1 dapat di klaim sebagai emping rendah purin. Hal ini dikarenakan total basa purin pada masing masing merek mengalami penurunan lebih besar dari 10\% (BPOM 2011). Namun untuk emping Sriti, karena penurunan total basa purinnya kurang dari $10 \%$ maka tidak dapat di klaim sebagai emping rendah purin.

\section{Hasil uji organoleptik}

Hasil uji organoleptik dapat dilihat pada Tabel 5. Hasil uji organoleptik dari sampel yang diberi perlakuan, baik Sriti maupun A1 berbeda nyata dibandingkan dengan sampel kontrol pada seluruh parameter organoleptik yang diuji. Sampel yang diberi perlakuan cenderung agak tidak disukai oleh panelis. Hal ini terlihat dari hasil uji organoleptik dimana baik sampel Sriti maupun A1 yang telah diberi perlakuan perendaman memiliki nilai kisaran $3-4$ yang menunjukan panelis memiliki respon agak tidak suka ataupun netral. Hal ini berbeda dengan sampel kontrol yang cenderung disukai oleh panelis dengan nilai uji organoleptik 5 - 6 yang menunjukan bahwa panelis agak suka ataupun menyukai emping tanpa perlakuan perendaman. Hasil uji ANOVA menunjukkan bahwa apabila dibandingkan dengan sampel kontrol, tingkat kesukaan sampel yang telah mengalami perendaman berbeda nyata dari sampel kontrol pada seluruh parameter organoleptik yang diuji. Selanjutnya hasil uji ANOVA menunjukkan bahwa antar sampel dengan perlakuan 2 jam perendaman terdapat perbedaan nyata pada warna, rasa dan overall. Hal ini menunjukan bahwa jenis emping yang berbeda akan berpengaruh terhadap tingkat kesukaan panelis setelah emping diberi perlakuan. Karena karakteristik fisik emping juga berbeda (Tabel 1), maka hal ini juga mengindikasikan perbedaan karakteristik fisik emping mentah akan mempengaruhi produk jadi emping setelah diberi perlakuan.

Tabel 5. Hasil uji organoleptik sampel emping melinjo goreng dari hasil percobaan perendaman dalam air untuk menurunkan kandungan basa purin*

\begin{tabular}{lcccccc}
\hline Sampel & $\begin{array}{c}\text { Lama } \\
\text { Perendaman }\end{array}$ & Warna & Aroma & Rasa & Tekstur & Overall \\
\hline Sriti & 2 jam & $3^{\mathrm{b}}$ & $4^{\mathrm{a}}$ & $4^{\mathrm{b}}$ & $4^{\mathrm{a}}$ & $4^{\mathrm{b}}$ \\
& 0 jam & $6^{\mathrm{c}}$ & $5^{\mathrm{b}}$ & $5^{\mathrm{c}}$ & $5^{\mathrm{b}}$ & $5^{\mathrm{c}}$ \\
$\mathrm{A} 1$ & $2 \mathrm{jam}$ & $3^{\mathrm{a}}$ & $4^{\mathrm{a}}$ & $3^{\mathrm{a}}$ & $4^{\mathrm{a}}$ & $3^{\mathrm{a}}$ \\
& 0 jam & $5^{\mathrm{c}}$ & $5^{\mathrm{c}}$ & $6^{\mathrm{c}}$ & $6^{\mathrm{b}}$ & $6^{\mathrm{c}}$ \\
\hline
\end{tabular}

Keterangan : * Nilai yang diikuti dengan huruf yang sama pada kolom yang sama menunjukan nilai yang tidak berbeda nyata $(\mathrm{p}<0.05)$. Uji organoleptik menggunakan rating hedonik dengan skala $1-7(1=$ sangat tidak suka, $7=$ sangat suka)

Ketidaksukaan panelis terhadap emping yang telah diberi perlakuan kemungkinan disebabkan perubahan fisik atau kimiawi emping selama proses perendaman. Emping A1 yang lebih tipis mengalami penurunan kualitas seperti dari segi warna yang lebih cepat setelah pengeringan dibandingkan emping Sriti yang lebih tebal karena memiliki luas permukaan yang lebih besar namun dikeringkan pada waktu dan suhu yang sama sehingga perubahan fisik ataupun kimiawinya lebih besar. Setelah diberi perlakuan, warna emping menjadi lebih gelap dibandingkan sebelumya. Perubahan ini dikarenakan reaksi pencoklatan non enzimatis yang terjadi selama proses pengeringan ulang (setelah perendaman). Reaksi pencoklatan non enzimatis dapat terjadi pada suhu $37^{\circ} \mathrm{C}$ (Benzing-Purdie et al. 1985) dan reaksinya relatif lebih cepat pada bahan pangan dengan kadar air $10-15 \%$ (Belitz dan Grosch 1999). Adapun ketidaksukaan terhadap rasa dan aroma diakibatkan adanya rasa gosong (burnt flavor) akibat penggorengan dari bahan hasil pengeringan kembali yang mungkin disebabkan oleh perubahan sebagian komponen karbohidrat yang lebih kompleks menjadi lebih sederhana sehingga memicu reaksi Maillard pada bahan selama penggorengan (Belitz dan Grosch 1999, Buckle et. al. 2009).

\section{Gambaran umum aplikasi metode}

Metode perendaman untuk menurunkan kadar adenin dan hiposantin pada emping sangat mudah diaplikasikan, baik oleh konsumen ataupun oleh produsen emping. Untuk konsumen, proses perendaman dapat dilakukan sebelum proses penggorengan dimana emping yang telah direndam dijemur terlebih dahulu sebelum digoreng. Proses ini membutuhkan waktu sekitar satu hari dimana 
emping mentah yang dihasilkan tidak akan terlalu kering namun tetap dapat digoreng. Emping mentah yang agak basah ini pun harus langsung digoreng, tidak boleh disimpan terlalu lama. Kadar air yang masih tinggi dapat memicu timbulnya kerusakan mikrobiologis (Buckle 2009).

Pada produsen, metode ini dapat diaplikasikan seutuhnya. Tentunya dengan memodifikasi proses pengeringan setelah perendaman sehingga mutu produk menjadi lebih baik dan seragam. Pengeringan buatan dapat dijadikan salah satu alternatif untuk proses pengeringan. Pengeringan ini menggunakan alat pengering dimana suhu, kelembaban udara, kecepatan pengaliran udara dan waktu pengeringan dapat diatur dan diawasi (Muchtadi dan Ayustaningwarno 2010). Namun, proses ini tentunya akan menambah biaya dan waktu proses dibandingkan produksi emping pada umumnya yang hanya dikeringkan melalui proses penjemuran. Proses pembuatan emping melinjo secara konvensional dapat dilihat pada Gambar 6A, sedangkan proses pembuatan emping melinjo dengan aplikasi metode direkomendasikan seperti pada Gambar 6B.

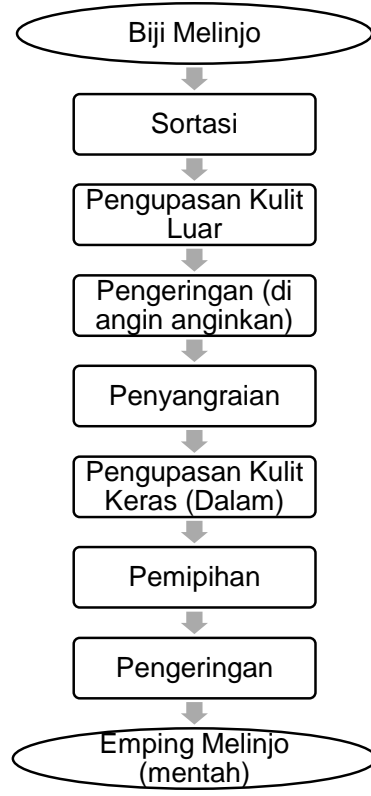

A
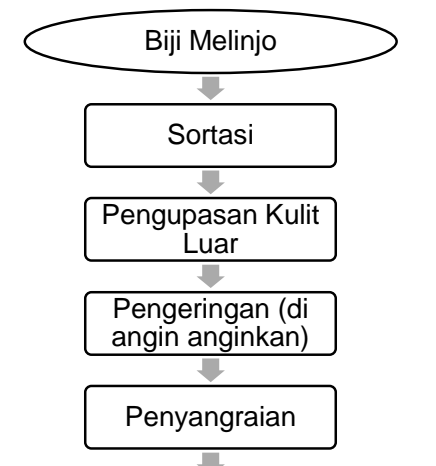
Keras (Dalam)

\section{Pemipihan}

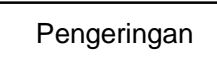

Pengeringan

Perendaman

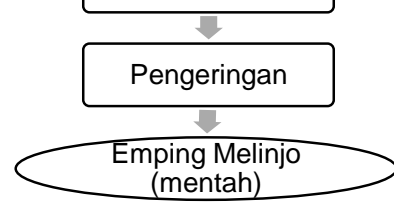

B

Gambar 6. Proses pembuatan emping melinjo secara konvensional $(A)$ dan dengan aplikasi metode $(B)$

\section{KESIMPULAN}

Metode perendaman emping mentah dalam air mampu mereduksi konsentrasi adenin dan hiposantin, yang merupakan basa purin pada emping melinjo. Perendaman selama 2 jam mampu menurunkan kadar

adenin dan hiposantin pada seluruh merek emping yang diuji dengan presentase penurunan adar adenin dan hiposantin yang berbeda. Emping merek Koki dan A1 dapat di klaim sebagai emping rendah purin karena mengalami penurunan total basa purin lebih dari $10 \%$. Emping melinjo yang telah diberikan perlakuan perendaman agak tidak disukai oleh panelis namun masih dapat diterima dari segi organoleptik. Terdapat perbedaan nyata antara emping melinjo kontrol dan emping yang telah diberikan perlakuan perendaman pada parameter warna, aroma, rasa, tekstur dan overall emping melinjo setelah digoreng.

\section{DAFTAR PUSTAKA}

[AOAC] Association of Official Analytical Chemist. 2012. Official Methods of Analysis. Association of Official Analytical Chemist, Washington DC.

[BPOM] Badan Pengawas Obat dan Makanan Republik Indonesia. 2011. Peraturan Kepala Badan Pengawas Obat dan Makanan tentang Pengawasan Klaim dalam Label dan Iklan Pangan Olahan.

Belitz HD, Grosch W. 1999. Food Chemistry. SpringerVerlag. Berlin, Germany. DOI: 10.1007/978-3-66207281-3.

Benzing-Purdie LM, Ripmeester JA, Ratcliffe CI. 1985. Effects of temperature on Maillard reaction products. J Agric Food Chem 33(1): 31-3. DOI: 10.1021/jf0 0061 a009.

Buckle KA, Edwards RA, Fleet GA, Wootton M. 2009. Ilmu Pangan. UI-Press. Jakarta

Choi HK, Liu S, Curhan G. 2005. Intake of purin-rich foods, protein, and dairy products and relationship to serum levels of uric acid. Arthritis Rheumatism 52(1): 283-9. DOI: 10.1002/art.20761.

Haryoto. 1998. Membuat Emping Melinjo. Kanisius. Yogyakarta.

Herskovits TT, Harrington JP. 1972. Solution studies of the nucleic acid bases and related model compounds. Solubility in aqueous alcohol and glycol solutions. Biochemistry 11(25): 4800-1. DOI: $10.1021 / \mathrm{bi} 00$ $775 \mathrm{a} 025$.

Jankowska DA, Trautwein-Schult A, Cordes A, Hoferichter P, Klein C, Bode R, Baronian K, Kunze G. 2013. Arxula adeninivorans xanthine oxidoreductase and its application in the production of food with low purine content. J Appl Microbiol 115: 796807. DOI: 10.1111/jam.12284.

Kaneko K, Aoyagi Y, Fukuuchi T, Inazawa K, Yamaoka N. 2014. Total purine and purine base content of common foodstuffs for facilitating nutritional therapy for gout and hyperuricemia. Biol Pharm Bull 37(50): 709-21. DOI: 10.1248/bpb.b13-00967.

Kaneko K, Kudo Y, Yamanobe T, Mawatari K, Yasuda, M, Nakagomi K, Fujimori S. 2008. Purine content of soybean-derived foods and selected japanese 
vegetables and mushrooms. Nucleosides Nucleotides Nucleic Acids 27: 628-30. DOI: 10.1080/1525777 0802138681.

Konno H, Kanal Y, Katagiri, M, Watanabe T, Mori A, Ikuta T, Tani H, Fukushima S, Tatefuji T, Shirasawa T. 2013. Melinjo (Gnetum gnemon L.) seed Extract Decreases Serum Uric Acid Levels in Nonobese Japanese males: A Randomized Controlled Study. In: Evidence-Based Complementary and Alternative Medicine. Hindawi Publishing Corporation. DOI: 10.1155/2013/589169.

Lim J. 2011. Hedonic scaling: A review on methods and theory. Food Qual Prefer 22: 733-47. DOI: 10.101 6/j.foodqual.2011.05.008.

Muchtadi TR, Ayutaningwarno F. 2010. Teknologi Proses Pengolahan Pangan. Alfabeta. Bandung
Munajad A. 2009. Nilai gizi emping melinjo. [terhubung berkala]. [http://empingmelinjo5s3.com/kandungangizi-emping-melinjo.html]. [Agustus 2013].

Sayuti K, Yenrina R, Refdi CW, Fajri PY. 2019. Adenine, guanine, xanthine and hypoxanthine content in various Indonesian foods. Pak J Nutr 18(3): 260-3. DOI: 10.3923/pjn.2019.260.263.

Tarkeltaub R. 2010. Update on gout: new therapeutic strategies and option. Nat Rev Rheumatol 6: 30-3. DOI: 10.1038/nrrheum.2009.236.

Xue XF, Zhou JH, Wu LM, Fu LH, Zhou J. 2009. HPLC determination of adenosine in royal jelly. Food Chem 115: $715-719$ DOI: $10.1016 /$ j.foodchem.2008.1 2.003 .

JMP-06-19-17-Naskah diterima untuk ditelaah pada 26 Juni 2019. Revisi makalah disetujui untuk dipublikasi pada 19 September 2019. Versi Online: http://journal.ipb.ac.id/index.php/jmpi 